\title{
Effect of histological processing and methacrylate sectioning on the area of gill tissue in teleost
}

\author{
Cruz, AL. ${ }^{\mathrm{a}}$, Fernandes, $M N{ }^{\mathrm{a} *}$ and Perry, SF. ${ }^{\mathrm{b}}$

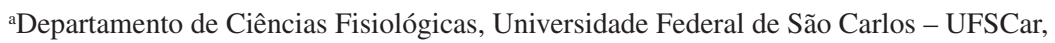 \\ CEP 13565-905, São Carlos, SP, Brazil \\ ${ }^{b}$ Institut für Zoologie, Universität Bonn, 53115, Bonn, Germany \\ *e-mail:dmnf@power.ufscar.br \\ Received July 26, 2007 - Accepted October 3, 2007 - Distributed May 31, 2009
}

(With 2 figures)

\begin{abstract}
Deformation of biological tissues may occur during histological processing and results in loss of accuracy when quantitative information about cells, tissues and organs is necessary. In this study, the gill tissue from armored catfish (Pterygoplichthys anisitsi) was quantified in each step of processing using the stereological principles. During processing for glycol methacrylate embedding, gill tissue from shrinks significantly but regains its original dimensions after sectioning.
\end{abstract}

Keywords: gills, morphometry, methacrylate, shrinkage, armored catfish.

\section{Efeito do processamento histológico e seccionamento em metacrilato sobre a área de tecido branquial em teleósteo}

\begin{abstract}
Resumo
Deformações nos tecidos podem ocorrer durante o processamento histológico e resultar em informações errôneas quando há necessidade de dados quantitativos sobre células, tecidos e órgãos. Neste estudo, o tecido branquial do cascudo (Pterygoplichthys anisitsi) foi quantificado em cada etapa do processamento utilizando os princípios de estereologia. O tecido branquial reduziu significativamente durante processamento histológico com metacrilato, mas retornou às suas dimensões iniciais depois de seccionadas, o que indica não ocorrer nenhuma perda na informação quantitativa do tecido.
\end{abstract}

Palavras-chave: brânquias, morfometria, metacrilato, redução de área branquial, cascudo.

\section{Introduction}

Although stereological methods have been used for the quantitative evaluation of vertebrate respiratory organs for more than 35 years (Weibel, 1963), their application to gills has remained rudimentary (Hughes, 1972). Recently a stereological method was described for determination of surface areas in gills (Costa et al., 2007) and applied to the gills, lungs, skin (Moraes et al., 2005) and accessory respiratory organs of Brazilian fish species. Some doubt remains however, if distortion of the tissue during histological processing and sectioning might lead to systematic error in surface area determinations.

In order to test the hypothesis that the projected area of sectioned tissue differs significantly from that of fresh tissue, the gill tissue samples from one fish species were processed for sectioning using ethanol and embedding in glycol methacrylate. The projected area of the tissue profile during processing and after sectioning was determined in order to evaluate if systematic changes occur.

\section{Material and Methods}

Gill tissue (Figure 1a) from armored catfish, Pterygoplichthys anisitsi Eigenmann and Kennedy $1903, \mathrm{n}=6$, body mass $=252.5 \pm 23.7 \mathrm{~g}$, were fixed in $2.5 \%$ phosphate-buffered glutaraldehyde and dehydrated through graded ethanol solutions to $100 \%$, ethanol:unccelerated methacrylate $(1: 1)$ and finally accelerated methacrylate (Historesin $\left.{ }^{\circledR}\right)$. The sections $(3 \mu \mathrm{m}$ in thickness) were stretched on water, placed on glass slides, stained with $0.5 \%$ toluidine blue, dehydrated and mounted for light microscopy.

The projected area of the fresh tissue sample was determined by point counting (Howard and Reed, 1998) us- 
ing a stereomicroscope equipped with a drawing tube for visualizing the test array (Perry et al., 1994). The same tissue samples were measured at each stage of processing using identical hardware until sectioning. After sectioning (Figure 1b), the number of points on a rectangular point array overlapping the profile of the sectioned tissue in the block $\left(\mathrm{P}_{\mathrm{B}}\right)$ was compared with the number over the mounted and stained section $\left(\mathrm{P}_{\mathrm{S}}\right)$. The numerical relationship $\mathrm{P}_{\mathrm{S}} / \mathrm{P}_{\mathrm{B}}$, multiplied by the point count of the embedded tissue before sectioning, was proportional to the area of the tissue block.

One-way ANOVA with Tukey test for multiple comparisons (Zar, 1999) was used to compare the difference between means of the proportional changes of standardized data at each stage of histological processing for the species. The statistical test analyses were done with a $95 \%$ confidence limit $(\mathrm{p}<0.05)$.

\section{Results and Discussion}

Most quantitative studies are done using histological sections and the images observed under the microscope may present differences in their two dimensions in relation to the in vivo tissue (Ladekarl, 1994, Dorph-Petersen et al., 2001). Thus, preliminary analyses are important to detect tissue deformation during processing to avoid overestimating or underestimating data before the morphometrical study with potential relevance to biological and physiological responses.

The point count data for the determination of area of gill tissue is given in Table 1. The total number of points reflects experimenter-determined differences in sample size and point density of the matrices used for evaluation and are therefore of no biological significance. The results (Table 1) were standardized by dividing the point count for each consecutive processing condition (until sectioning) by that for the fresh tissue and multiplying by 100 and the linear and volumetric values, the $1 / 2$ power (linear) or the $3 / 2$ power (volumetric) of the empirically point counted (proportional to the projected area) were then determined. The normalized data (per 100 points in fresh tissue) are shown in Table 2.

The estimated linear and volumetric determinations showed in Figure 2 reveals that dehydration causes significant overall reduction in the area of gill tissue $(p<0.05)$, which is compensated by stretching after sectioning.

In conclusion, the projected area based upon the histological section does not differ significantly from that of the fresh tissue in the histological processing of gill tissue of $P$. anisitsi. Calculated values for linear and volumetric changes show identical patterns to those calculated for area. Thus, surface area, barrier thickness and volumetric determinations based on methacrylate sections provide a
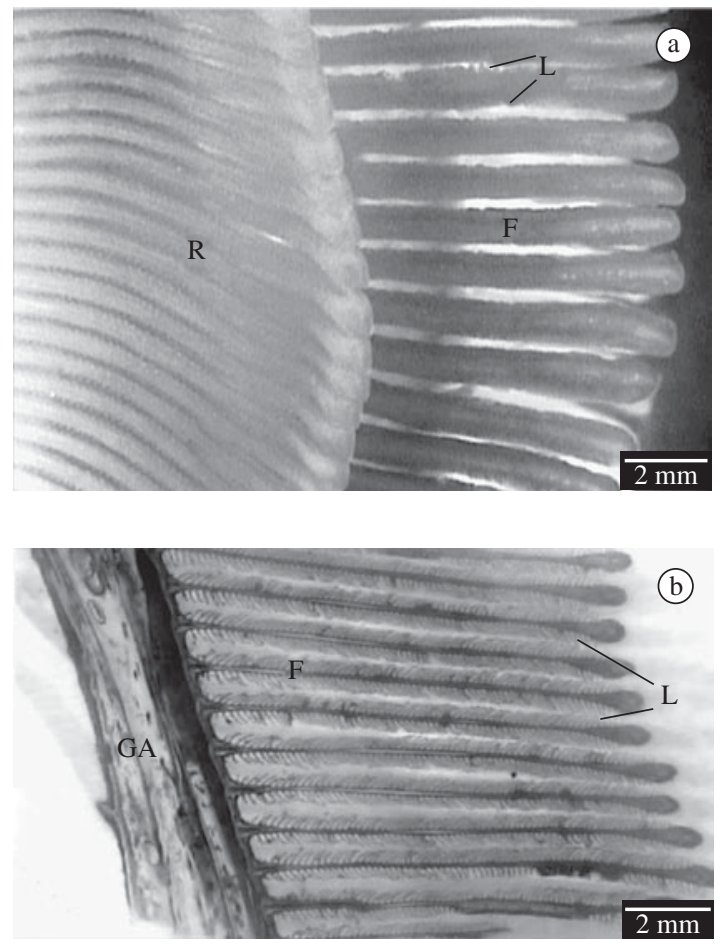

Figure 1. a) Gill tissue from $P$. anisitsi showing the rakers (R) and filaments (F) and lamella (L); and b) section of the gill tissue embedded in glycol methacrylate showing the filaments (F) and the lamella (L) above and below the filament axis. GA, gill arch.

Table 1. Points counted over projected area of gill tissue sample of the armored catfish, $P$. anisitsi, in each stage of histological processing.

\begin{tabular}{ccccccc}
\hline Fish & Fresh & Fixed & Dehydrated & Embedded & Block & Section \\
\hline 1 & 34 & 26 & 24 & 24 & 24 & 28 \\
2 & 24 & 22 & 20 & 21 & 20 & 25 \\
3 & 21 & 20 & 20 & 20 & 19 & 25 \\
4 & 27 & 25 & 21 & 22 & 18 & 27 \\
5 & 27 & 25 & 23 & 22 & 20 & 25 \\
6 & 28 & 26 & 21 & 22 & & 24 \\
\hline
\end{tabular}


Table 2. Standardized changes in tissues dimensions due to gill tissue processing for light microscopy.

\begin{tabular}{lcccccc}
\hline \multicolumn{1}{c}{ Dimensions } & Fresh & Fixed & Dehydrated & Embedded & Block & Section \\
\hline Linear $(\mathrm{mm})$ & $10(0)$ & $9.49(0.15)$ & $9.00(0.19)$ & $9.07(0.18)$ & $8.74(0.20)$ & $9.84(0.27)$ \\
Area $\left(\mathrm{mm}^{2}\right)$ & $100(0)$ & $90.23(2.79)$ & $81.18(3.56)$ & $82.47(3.40)$ & $76.71(3.65)$ & $97.31(5.50)$ \\
Volumetric $\left(\mathrm{mm}^{3}\right)$ & $1000(0)$ & $858.75(38.66)$ & $734.14(48.63)$ & $751.41(46.47)$ & $674.72(48.57)$ & $965.65(82.58)$ \\
\hline
\end{tabular}

Empirical data indicated in boldface type. Other values calculated (see text). Mean values $(n=6)$. Standard errors of means in parentheses.

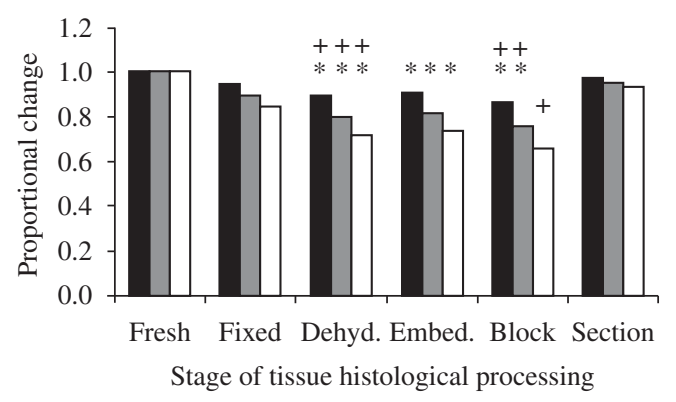

Figure 2. Proportional changes in linear (black column), area (striped column) and volumetric (white column) dimensions of gill tissue in the armored catfish (Pterygoplichthys anisiti) during processing for methacrylate sectioning. *indicates significant difference $(\mathrm{p}<0.05)$ from fresh tissue; + indicates significant differences $(\mathrm{p}<0.05)$ from sectioned tissue.

reliable estimate of the condition in the fresh gills without correction for tissue distortion.

Acknowledgements - We thank CAPES (Brazil) and DAAD (Germany) for the financial support to MNF and SFP (Probral Program, Projeto. 116/00) and CAPES for the scholarship to AL Cruz.

\section{References}

COSTA, OTF., PEDRETTI, ACE., SCHMITZ, A., PERRY, SF. and FERNANDES, MN., 2007. Stereological estimation of surface area and barrier thickness of fish gills in vertical sections. Journal of Microscopy, vol. 225, no. 1, p. 1-9.

DORPH-PETERSEN, KA., NYENGAARD, JR. and GUNDERSEN, HJG., 2001. Tissue shrinkage and unbiased stereological estimation of participle number and size. Journal of Microscopy, vol. 204, no. 3, p. 232-246.

HOWARD, CV. and REED, MG., 1998. Unbiased stereology: three-dimensional measurement in microscopy. Oxford: Bios Scientific Publishers.

HUGHES, GM., 1972. Morphometrics of fish gills. Respiratory Physiology, vol. 14, no. 1, p. 1-25.

LADEKARL, M., 1994. The influence of tissue processing on quantitative histopathology in breast cancer. Journal of Microscopy, vol. 174, no. 1, p. 93-100.

MORAES, MFPG., HÖLLER, S., COSTA, OTF., GLASS, ML., FERNANDES, MN. and PERRY, SF., 2005. Morphometric comparison of the respiratory organs of the South American lungfish, Lepidosiren paradoxa (Dipnoi). Physiological and Biochemical Zoology, vol. 78, no. 4, p. 546-559.

PERRY, SF., HEIN, J. and VAN DIEKEN, E., 1994. Gas exchange morphometry of the lungs of the tokay, Gekko gecko L. (Reptilia:Squamata:Gekkonidae). Journal of Comparative Physiology B, vol. 164, no. 2, p. 206-214.

WEIBEL, ER., 1963. Morphometry of the human lung. London; New York: Academic Press.

ZAR, JH., 1999. Biostatistical analysis. New Jersey: Prentice Hall. 
